\title{
Reproductive parameters of Phytoseiulus macropilis (Banks) fed with Tetranychus urticae Koch (Acari: Phytoseiidae, Tetranychidae) in laboratory
}

\author{
G. C. Souza-Pimentel ${ }^{a}$, P. R. Reis ${ }^{b}$, C. R. Bonatto ${ }^{c}$, J. P. Alves ${ }^{c}$ and M. F. Siqueira \\ aPostgraduate Program in Entomology, Universidade Federal de Lavras - UFLA, CP 3037, CEP 37200-000, Lavras, MG, Brazil \\ bEmpresa de Pesquisa Agropecuária de Minas Gerais - EPAMIG/EcoCentro, CP 176, CEP 37200-000, Lavras, MG, Brazil \\ 'Universidade Federal de Lavras - UFLA, CP 3037, CEP 37200-000, Lavras, MG, Brazil \\ *e-mail: gitostes@yahoo.com.br
}

Received: August 24, 2015 - Accepted: December 14, 2015 - Distributed: February 28, 2017

(With 1 figure)

\begin{abstract}
Predatory mites that belong to the Phytoseiidae family are one of the main natural enemies of phytophagous mites, thus allowing for their use as a biological control. Phytoseiulus macropilis (Banks, 1904) (Acari: Phytoseiidae) is among the main species of predatory mites used for this purpose. Tetranychus urticae Koch, 1836 (Acari: Tetranychidae) is considered to be one of the most important species of mite pests and has been described as attacking over 1,100 species of plants in 140 families with economic value. The objective of the present study was to investigate, in the laboratory, the reproductive parameters of the predatory mite P. macropilis when fed T. urticae. Experiments were conducted under laboratory conditions at $25 \pm 2{ }^{\circ} \mathrm{C}$ of temperature, $70 \pm 10 \% \mathrm{RH}$ and 14 hours of photophase. In addition, biological aspects were evaluated and a fertility life table was established. The results of these experiments demonstrated that the longevity of adult female was 27.5 days and adult male was 29.0 days. The population was estimated to increase approximately 27 times $\left(\mathrm{R}_{\mathrm{o}}\right)$ in mean generation time $(\mathrm{T})$, which was 17.7 days. Lastly, the mite population grew 1.2 times/day $(\lambda)$ and doubled every 3.7 days (TD).
\end{abstract}

Keywords: agricultural acarology, two-spotted spider mite, fertility life table, biology, biological control.

\section{Parâmetros reprodutivos de Phytoseiulus macropilis (Banks) predando Tetranychus urticae Koch (Acari: Phytoseiidae, Tetranychidae) em laboratório}

\begin{abstract}
Resumo
Os ácaros predadores pertencentes à família Phytoseiidae constituem um dos principais inimigos naturais de ácaros fitófagos, o que possibilita o seu uso em controle biológico. Entre as principais espécies destaca-se Phytoseiulus macropilis (Banks, 1904) (Acari: Phytoseiidae). O ácaro Tetranychus urticae Koch, 1836 (Acari: Tetranychidae) é considerado uma das espécies de ácaros-praga mais importantes, atacando mais de 1.100 espécies de plantas em 140 famílias de valor econômico. Este trabalho foi realizado com o objetivo de estudar, em laboratório, os parâmetros reprodutivos do ácaro predador P. macropilis, quando alimentado com T. urticae. Os estudos foram conduzidos em laboratório à temperatura de $25 \pm 2{ }^{\circ} \mathrm{C}, 70 \pm 10 \%$ de UR e 14 horas de fotofase e foram avaliados os aspectos biológicos e confeccionada a tabela de vida de fertilidade. Foi constatada uma longevidade de 27,5 dias para fêmeas adultas e 29,0 dias para machos. A população foi estimada em aumentar aproximadamente 27 vezes $\left(R_{0}\right)$ no período médio de duração de geração $(T)$ que foi de 17,7 dias. A população do ácaro cresceu 1,2vezes/dia ( $\lambda$ ) e dobrou a cada 3,7 dias (TD).
\end{abstract}

Palavras-chave: acarologia agrícola, ácaro-rajado, tabela de vida de fertilidade, biologia, controle biológico.

\section{Introduction}

Predatory mites that belong to the Phytoseiidae family are one of the main natural enemies of phytophagous mites in the cultivation of rosebush (Rosa spp.) as well as of other ornamental and horticultural crops produced in greenhouses (Silva et al., 2005). Phytoseiidae mites find favorable conditions in greenhouses, allowing for their use in biological control. Phytoseiulus macropilis (Banks, 1904) (Phytoseiidae) is one of the main predatory mites used in greenhouses (Reis et al., 2005; Oliveira et al., 2007, 2009). 
Studies involving the use of predatory mites for biological control are worldwide common (McMurtry et al., 2015). In Brazil, for example, P. macropilis and Neoseiulus californicus (McGregor, 1954) are commonly studied, and in addition to being efficient in the control of the Tetranychus urticae (Koch, 1836) (Tetranychidae) in various crops, they are commercially produced, which allows for their mass liberation in crops (Sato et al., 2002; Poletti et al., 2006).

Studies carried out in Brazil using predatory mites, especially $P$. macropilis and $N$. californicus, have shown that these are potential species for the control of T. urticae, mainly in protected cultivation areas (Poletti et al., 2006).

The two-spotted spider mite is considered one of the most important species of mite pests because it is cosmopolitan and polyphagous. This species has been described as attacking over 1,100 plant species in 140 families of economic value (Grbić et al., 2011). The two-spotted spider mite is a pest that attacks fruit and berry plants such as the strawberry plant (Fragaria spp., Rosaceae), papaya tree (Carica papaya L., Caricaceae), peach tree (Prunus persica L., Rosaceae), and others as well as ornamental plants such as chrysanthemum (Chrysanthemum spp., Asteraceae) and roses (Rosa spp., Rosaceae) among others (Chapman and Martin, 2005; Fadini et al., 2006; Moraes and Flechtmann, 2008).

In a greenhouse, the developmental cycle of the T. urticae mite varies considerably in relation to temperature. In hot and dry conditions, it may complete its cycle in only seven days since high temperatures and low relative humidity favors its development. The biological cycle, from egg to adult, has an average duration of ten days; it is adaptable and presents a high capacity to develop resistance to phytosanitary products (Reis et al., 2005; Silva et al., 2009).

The relatively stable environmental conditions that are maintained for plant development in greenhouses generally facilitate rapid pest development, with pest populations often increasing significantly even before producers notice them. Since greenhouses are closed and artificial environments, the presence of natural enemies to these pests inside greenhouses is almost inexistent, which favors a rapid resistance through selection to the pesticides used in greenhouses (Zhang, 2003).

The usual method to control the two-spotted spider mite is with a synthetic mite killer (Sato et al., 2007). Nevertheless, in many situations, synthetic mite killers have led to the selection of resistant populations, creating the need for additional pulverizations and/or an increase of the dose applied (Sato et al., 2007, 2009).

A study of pests that occur in rosebush cultivation, especially the two-spotted spider mite, is necessary to develop a biological control method, less damaging to the health of rose producers and more favorable to environmental preservation. The present study addresses the biological control of this pest with predatory mite, $P$. macropilis referencing successful experiments that have been done worldwide with diverse crops cultivated in greenhouses (Opit et al., 2004; Alatawi et al., 2011; Ferrero et al., 2011).
There is a need for the permanent study on the management of pests found in protected cultivation systems in order to ensure an efficient, economic, and ecologically sustainable control. To do this, knowledge of biological and efficiency of predators of pests also becomes necessary. The present study was carried out with the objective of investigating, under laboratory conditions, the reproductive parameters of the predatory mite P. macropilis when fed with T. urticae.

\section{Material and Methods}

The present study was conducted under controlled conditions with a temperature of $25 \pm 2{ }^{\circ} \mathrm{C}, \mathrm{RH}$ of $70 \pm 10 \%$, and 14 hours of photophase in the Acarology Laboratory of the EPAMIG-Sul de Minas - Research Center of Ecology Management of Pests and Plant Diseases - EcoCentro, Lavras, MG.

\subsection{Rearing of two-spotted spider mite}

Uncapped Petri dishes (15 $\mathrm{cm}$ in diameter) were used and $1 \mathrm{~cm}$ thick foam, which was maintained moist with distilled water, covered the entire bottom surface of each dish. A Jack-bean leaflet [Canavalia ensiformis L. (DC), Fabaceae] was placed on top of the foam and surrounded by strips of cotton that were also in contact with the damp foam in order to prevent the mites from escaping and to better conserve the leaflet. Mite pests (T. urticae) were placed on the Jack-bean leaflets, which were switched out weekly.

\subsection{Rearing of predatory mite}

The predatory mites, P. macropilis, were originally obtained from the Instituto Federal de Educação, Ciência e Tecnologia do Sul de Minas - Campus de Inconfidentes. The mites were reared in the laboratory and kept there throughout the project to ensure that there were enough mites to complete the study.

For the laboratory maintenance rearing, P. macropilis was placed on arenas of black flexible PVC plastic sheets $(26 \times 22 \mathrm{~cm})$. These were put over Styrofoam of equal size, and in turn these were placed in water on plastic trays $(32 \times 26.5 \times 5.5 \mathrm{~cm})$. Cotton was placed around the Styrofoam and the arena and it was in contact with the water from the tray. The cotton was used to prevent the mites from escaping in addition to preserving the Jack-bean leaves. The leaves were placed on the arenas with the petiole over the damp cotton and were infested by mite pests, which served as food for predators.

Based on the methodology adapted from McMurtry and Scriven (1964), as the leaves withered, other new leaves infested by T. urticae were placed over the old leaves. This system is commonly used for acquiring a large number of predators in each rearing unit, which is important as it ensures that predatory mites are available in every stage of the project.

\subsection{Biological cycle stages}

In order to study the biological parameters of P. macropilis, its embryonic development, post-embryonic development, and fertility life table were evaluated using all stages of 
T. urticae as its prey, sufficient to develop the predatory each phase (ad libitum).

\subsubsection{Embryonic development}

During laboratory rearing, forty-three eggs of the predator $P$. macropilis were individually collected less than 12 hours after hatching and maintained on Jack-bean leaf discs (3 cm in diameter) placed inside Petri dishes $5 \mathrm{~cm}$ in diameter filled with agar-water at $3 \%$. The dishes were covered with PVC film to impede ecloded larvae from escaping. Each egg was observed daily, at 8:00 a.m. and 4:00 p.m. (Reis et al., 1998), to determine the approximate moment of the larval eclosion.

\subsubsection{Post-embryonic development}

In the post embryonic development stage the predator was fed with the mite pest T. urticae. As in the study of embryonic development, specimen observation was done twice daily, at 8:00 a.m. and 4:00 p.m., for both the larvae and nymph immature stages. After the larvae eclosion, the duration, in days, of each mite developmental stage was observed: larvae, protonymph, deutonymph, adult-egg period, and the longevity of males and females. Forty-three specimens were used for the evaluation of the predator P. macropilis in the adult stage.

To study of the mites in the adult stage, 43 pairs were formed using females still in the deutonymph stage and males from the maintenance rearing. From those 43 pairs, 29 couples were studied. Others substituted males that died from the laboratory rearing. Each couple was confined in Petri dishes ( $5 \mathrm{~cm}$ of diameter) with agar-water and a Jack-bean leaf, as described previously. The stages of pre-oviposition, oviposition and post-oviposition, as well as total female and male longevity were observed beginning with the couples' formation, according to the methodology described by Reis et al. (2007). Only one observation a day, at 4:00 p.m., was done in the adult stage.

The predators were fed a large amount of prey daily, about 30 specimens, which is more than enough for the development of the predator.

\subsubsection{Fertility life table}

The fertility life table of $P$. macropilis was established using survival data $(l x)$, specific fertility $\left(m_{x}\right)$, and sex ratio, all of females still in the deutonymph stage. As previously mentioned, each deutonymph along with a male was placed in a Petri dish ( $5 \mathrm{~cm}$ in diameter) with agar-water and arenas of Jack-bean leaves, and observed every 24 hours. Eggs laid by females during the oviposition stage as well as dead adult mites were counted and removed.

The methodology of Andrewartha and Birch (1954) apud Silveira Neto et al. (1976) was used in establishing the fertility life table. Using the data obtained such as age interval $(x)$, specific fertility $\left(m_{x}\right)$, and survival probability $\left(l_{x}\right)$, the following values were calculated: $\mathrm{R}_{\mathrm{o}}=\sum m_{x} \cdot l_{x}$ (the net reproductive rate or the number of times the population increases in each generation), $\mathrm{T}=\sum m_{x} \cdot l_{x} \cdot x / \sum m_{x} \cdot l_{x}$, (time interval of each generation), $\mathrm{r}_{\mathrm{m}}=\operatorname{lnR}_{\mathrm{o}} / \mathrm{T}$ (intrinsic rate of population increase), $\lambda=\mathrm{e}^{\mathrm{rm}}$ (finite rate of increase), and
TD (doubling time or the time necessary for the population to double in number) which according to Tanigoshi et al. (1975) is equal to $\ln 2 / \mathrm{r}_{\mathrm{m}}$.

\section{Results}

\subsection{Biological cycle phases}

The duration, in days, of post-embryonic stages for both female and male, the egg to adult development period, the longevity and sexual ratio are reported in Table 1 . The average period, in days, of the P. macropilis pre-oviposition, oviposition, post-oviposition, fertility of female and the number of eggs laid by them every day are reported in Table 2 .

\subsection{Fertility life table}

A fertility life table of $P$. macropilis fed with T. urticae is shown in Table 3. Phytoseiulus macropilis population was estimated to increase approximately 27 times $\left(\mathrm{R}_{\mathrm{o}}\right)$

Table 1. Duration in days (Mean $\pm \mathrm{SE}$ ) of the developmental stages, biological cycle, and sex ratio of Phytoseiulus macropilis, at $25 \pm 2{ }^{\circ} \mathrm{C}, 70 \pm 10 \%$ of $\mathrm{RH}$, and 14 hours of photophase, when fed Tetranychus urticae.

\begin{tabular}{lccc}
\hline $\begin{array}{c}\text { Developmental } \\
\text { stages and } \\
\text { biological cycle }\end{array}$ & Sex & $\mathbf{N}^{\mathbf{1}}$ & $\begin{array}{c}\text { Duration in days } \\
\text { Mean } \pm \mathbf{S E}^{\mathbf{2}}\end{array}$ \\
\hline Egg & Female & 29 & $1.72 \pm 0.09$ \\
Larvae & Male & 14 & $1.82 \pm 0.13$ \\
Frotonymph & Memale & 29 & $0.42 \pm 0.02$ \\
Female & 14 & $0.45 \pm 0.02$ \\
Deutonymph & Male & 14 & $1.03 \pm 0.10$ \\
Egg-Adult & Female & 29 & $0.88 \pm 0.07$ \\
& Male & 14 & $1.21 \pm 0.16$ \\
Longevity & Female & 29 & $4.13 \pm 0.09$ \\
& Male & 14 & $5.14 \pm 0.16$ \\
Sex ratio & Female & 29 & $27.52 \pm 1.79$ \\
\hline N & Male & 14 & $29.00 \pm 3.32$ \\
\hline
\end{tabular}

${ }^{1} \mathrm{~N}=$ Number of specimens observed. ${ }^{2} \mathrm{SE}=$ Standard error of the mean.

Table 2. Duration in days (Mean \pm SE) of the stages and reproductive parameters of Phytoseiulus macropilis, at $25 \pm 2{ }^{\circ} \mathrm{C}, 70 \pm 10 \% \mathrm{RH}$, and 14 hours of photophase, when fed Tetranychus urticae.

\begin{tabular}{lcc}
\hline $\begin{array}{c}\text { Stages and reproductive } \\
\text { parameters }\end{array}$ & $\mathbf{N}^{\mathbf{1}}$ & $\begin{array}{c}\text { Duration in } \\
\text { days } \\
\text { Mean } \pm \mathbf{S E}^{2}\end{array}$ \\
\hline Pre-oviposition & 29 & $2.57 \pm 0.66$ \\
Oviposition & 29 & $17.53 \pm 1.44$ \\
Post-oviposition & 29 & $7.46 \pm 1.79$ \\
Number of eggs/female & 29 & $48.34 \pm 4.28$ \\
Number of eggs/female/day & 29 & $2.72 \pm 0.13$ \\
\hline
\end{tabular}

${ }^{1} \mathrm{~N}=$ Number of specimens observed. ${ }^{2} \mathrm{SE}=$ Standard error of the mean. 
Table 3. Life fertility table of Phytoseiulus macropilis, at 25 $\pm 2{ }^{\circ} \mathrm{C}, 70 \pm 10 \%$ of $\mathrm{RH}$ and 14 hours of photophase, when fed Tetranychus urticae.

\begin{tabular}{|c|c|c|c|c|}
\hline$x^{1}$ & $m x^{2}$ & $l x^{3}$ & $m x . l x$ & $m x \cdot l x \cdot x$ \\
\hline 7.50 & 0.09 & 1.00 & 0.09 & 0.68 \\
\hline 8.50 & 0.46 & 1.00 & 0.46 & 3.91 \\
\hline 9.50 & 1.22 & 1.00 & 1.22 & 11.59 \\
\hline 10.50 & 1.46 & 1.00 & 1.46 & 15.33 \\
\hline 11.50 & 1,36 & 1.00 & 1.36 & 15.64 \\
\hline 12.50 & 1.76 & 1.00 & 1.76 & 22.00 \\
\hline 13.50 & 2.06 & 1.00 & 2.06 & 27.81 \\
\hline 14.50 & 1.83 & 0.97 & 1.78 & 25.74 \\
\hline 15.50 & 2.01 & 0.97 & 1.95 & 30.22 \\
\hline 16.50 & 1.73 & 0.97 & 1.68 & 27.69 \\
\hline 17.50 & 1.96 & 0.97 & 1.90 & 33.27 \\
\hline 18.50 & 1.78 & 0.90 & 1.60 & 29.64 \\
\hline 19.50 & 1.66 & 0.90 & 1.49 & 29.13 \\
\hline 20.50 & 1.36 & 0.87 & 1.18 & 24.12 \\
\hline 21.50 & 1.66 & 0.86 & 1.43 & 30.69 \\
\hline 22.50 & 1.02 & 0.83 & 0.85 & 19.05 \\
\hline 23.50 & 1.04 & 0.79 & 0.82 & 19.31 \\
\hline 24.50 & 1.32 & 0.79 & 1.04 & 25.55 \\
\hline 25.50 & 1.09 & 0.72 & 0.78 & 20.01 \\
\hline 26.50 & 1.02 & 0.72 & 0.73 & 19.46 \\
\hline 27.50 & 1.04 & 0.58 & 0.60 & 16.59 \\
\hline 28.50 & 0.51 & 0.58 & 0.30 & 8.43 \\
\hline 29.50 & 0.69 & 0.47 & 0.32 & 9.57 \\
\hline 30.50 & 0.49 & 0.47 & 0.23 & 7.02 \\
\hline 31.50 & 0.25 & 0.43 & 0.11 & 3.39 \\
\hline 32.50 & 0.23 & 0.39 & 0.09 & 2.92 \\
\hline 33.50 & 0.21 & 0.39 & 0.08 & 2.74 \\
\hline 34.50 & 0.16 & 0.39 & 0.06 & 2.15 \\
\hline 35.50 & 0.16 & 0.28 & 0.04 & 1.59 \\
\hline 36.50 & 0.16 & 0.28 & 0.04 & 1.64 \\
\hline 37.50 & 0.12 & 0.25 & 0.03 & 1.10 \\
\hline 38.50 & 0.05 & 0.25 & 0.01 & 0.48 \\
\hline 39.50 & 0.02 & 0.25 & 0.01 & 0.20 \\
\hline 40.50 & 0.02 & 0.25 & 0.01 & 0.20 \\
\hline 41.50 & 0.07 & 0.18 & 0.01 & 0.52 \\
\hline 42.50 & 0.00 & 0.14 & 0.00 & 0.00 \\
\hline 43.50 & 0.00 & 0.14 & 0.00 & 0.00 \\
\hline 44.50 & 0.00 & 0.07 & 0.00 & 0.00 \\
\hline 45.50 & 0.00 & 0.00 & 0.00 & 0.00 \\
\hline$\sum$ & & & $\mathrm{R}_{\mathrm{o}}=27.59$ & 489.37 \\
\hline
\end{tabular}

${ }^{1}$ Age interval. ${ }^{2}$ Specific fertility. ${ }^{3}$ Survival probability.

over the mean generation time (T), which was 17.74 days. The mite population increased 1.21 times/day $(\lambda)$ and doubled every 3.71 days (TD).

It was also observed that the survival rate $\left(l_{x}\right)$ and fecundity $\left(m_{\mathrm{r}}\right)$ of P. macropilis female mites decreased with as the age of the females increased (Figure 1). The maximum predator population increase occurred around the 13th day after the beginning of its development, and the maximum fecundity was 2.06 eggs (Table 3 ).

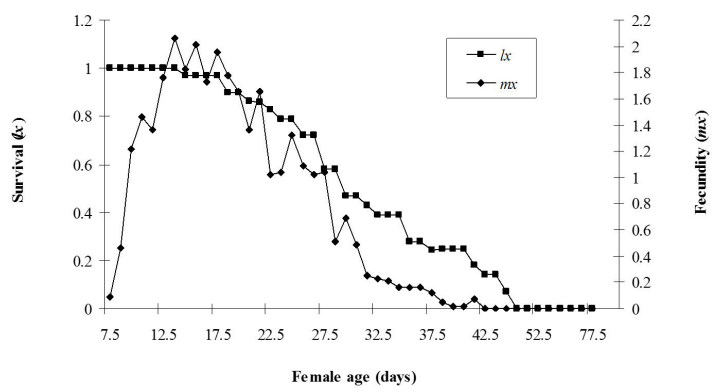

Figure 1. Survival $(l x)$ and fecundity $(m x)$ of female mite Phytoseiulus macropilis, fed with Tetranychus urticae, in relation to the age and in laboratory rearing at $25 \pm 2{ }^{\circ} \mathrm{C}$, $70 \pm 10 \%$ of RH, and 14 hours of photophase.

\section{Discussion}

\subsection{Biological cycle phases}

The average duration of the egg stage was a little over a day for both eggs that rendered females and eggs that rendered males.

The results of the present study were similar to results obtained by Prasad (1967), who in evaluating the development of P. macropilis fed with Tetranychus tumidus Banks, 1900 (Tetranychidae) at $26^{\circ} \mathrm{C}$ temperature, found durations of 1.8, 0.5, 0.9, and 1.0 days for the egg, larvae, protonymph, and deutonymph stages, respectively, and a development time from egg to adult of 4.2 days for females.

Escudero and Ferragut (2005) observed that the developmental stages of $P$. persimilis when fed with T. urticae had an average duration, in days, of 1.45 for the egg, 0.65 for the larvae, 1.0 for the protonymph, and 1.04 for the deutonymph. Davies et al. (2009) found values for $P$. persimilis of 0.6 and 1.4 days for the larvae and protonymph development, respectively, when fed with T. urticae.

Silva et al. (2005) investigated thermal requirements at five constant temperatures of P. macropilis fed with T. urticae. At $26^{\circ} \mathrm{C}$, duration periods of $2.0,1.1$, and 1.0 days were found for the stages of egg, protonymph, and deutonymph, respectively, and the adult-egg lasted 4.8 days. Similar results were obtained in the present study, except for the larvae stage that in Silva et al. (2005) lasted 0.8 days and in the present study lasted around 0.4 days. The different results found in the larvae stage could be related to the elapsed time between evaluations; in the present study, observations were done at 8:00 a.m. and 4:00 p.m. while in Silva et al. (2005) they were done every 12 hours nevertheless, in both studies the larval stage period was less than one day.

Ali (1998) investigated the effect of pollen and prey other than T. urticae on P. macropilis development at $25^{\circ} \mathrm{C}$. The predator completed its development in full when fed with T. urticae eggs and with prey in its immature stages. However, when the predator was fed with other prey its development was not completed. Ali (1998) also evaluated the effect of five different temperatures on the development 
of $P$. macropilis when the predator mite was fed with eggs of $T$. urticae. At $25^{\circ} \mathrm{C}$, the same temperature used in the present study, the author found higher results for almost all developmental stages of $P$. macropilis compared to the results found in this study, with the exception of the protonymph stage. In that stage, Ali (1998) reported a value of around 1.0 days for males and females; in the present study the values were similar for females and upper for males.

Mesa et al. (1990) compared T. urticae and Mononychellus progresivus Doreste, 1981 (Tetranychidae) as prey for P. macropilis. The results obtained in the present study were similar to results found by those authors, who found that the adult-egg development lasted 4.3 days when predator mites were fed with T. urticae, and 4.9 days when fed with M. progresivus. In Abad-Moyano et al. (2009), the duration of the adult-egg stage for $P$. persimilis fed with T. urticae was 4.44 days.

Vasconcelos (2006) observed that $P$. fragariae had a developmental duration of 2.2 and 0.7 days for eggs and larvae, respectively, when fed with $T$. urticae and an oviposition period of 8.1 days. Similar values were found for the $P$. macropilis in the present study. Although the specie $P$. fragariae investigated by Vasconcelos (2006) is different from the specie investigated in the present study, the similar results found can be related to the fact that both species belong to the same genus.

Silva et al. (2005) also found that at $26^{\circ} \mathrm{C}$ the pre-oviposition stage lasted 1.9 days. This result was less than the 2.57 days found in the present study at $25^{\circ} \mathrm{C}$. However, at the same temperature $\left(26^{\circ} \mathrm{C}\right)$, Silva et al. (2005) reported values higher than the current study for the other stages: oviposition, post-oviposition, and fecundity, as well as both female and male longevity.

Ali (1998) also reported higher values for the P. macropilis pre-oviposition and oviposition stages when fed with eggs or immature stages of the T. urticae, while the post-oviposition stage was a little shorter than found in the present study. In addition, the adults' longevity at $25^{\circ} \mathrm{C}$ was higher than the results found in the present study. Although the female's fecundity was higher, presenting 68.3 eggs/female, the oviposition rate was smaller than the results found in the present study. The sex ratio at $25^{\circ} \mathrm{C}$ was similar in both studies.

Prasad (1967) reported a shorter pre-oviposition period for $P$. macropilis than was found in the present study. However, an oviposition period of 20 days, longevity of 30 days for males and 27 days for females, and fecundity of $52 \mathrm{eggs} /$ female were similar to the results found in the present study. Although Prasad (1967) evaluated T. tumidus as the P. macropilis prey instead of T. urticae as used in the present study, similar results may have been found because the two species of mites belong to the same genus, Tetranychus.

In the study conducted by Mesa et al. (1990), the results found for the oviposition stage as well as for P. macropilis fecundity at $25{ }^{\circ} \mathrm{C}$ were higher than the results found in the present study.
Vasconcelos et al. (2008) also reported that the P. fragariae oviposition period lasted 17.1 days, which was close to the results found in the present study of 17.5, however, the longevity of males and females, as well as the fertility of $P$. fragariae fed with $T$. urticae, at the same temperature of this study were lower. Escudero and Ferragut (2005) and Abad-Moyano et al. (2009) assessing the biological aspects of $P$. persimilis when fed $T$. urticae found the oviposition rate of 3.9 and 3.7 eggs/female/day, respectively, which was higher.

As previously stated, all development phases of phytoseiid mites, both females and males, may have differences with respect to the period of its duration. The same can be observed for periods of pre-oviposition, oviposition, post-oviposition, female fertility and longevity of females and males. These differences may be related to different temperatures as in Silva et al. (2005), different phases of de pray supplied to the predatory mite as Ali (1998) and also the different mite species studied as Escudero and Ferragut (2005), Vasconcelos et al. (2008), and Abad-Moyano et al. (2009), thus making it necessary to more biological studies of predatory mites.

Therefore, the results presented in this study for $P$. macropilis were close to the results presented in the other studies done with $P$. fragariae and $P$. persimilis, the latter, one of the most studied mites and used to biological control in the world (Moraes, 2002).

\subsection{Fertility life table}

These results were similar both to those obtained by Silva et al. (2005) of $0.19 \mathrm{r}_{\mathrm{m}}$ at $26^{\circ} \mathrm{C}$ temperature and to those of Mesa et al. (1990) who reported that P. macropilis when fed with $M$. progresivus and T. urticae had $\mathrm{r}_{\mathrm{m}}$ values of 0.16 and 0.20 , respectively. Vasconcelos et al. (2008) also found an intrinsic rate of increase $\left(\mathrm{r}_{\mathrm{m}}\right)$ value for $P$. fragariae biology similar to what was found in the present study.

The main parameter of the life table is represented by the intrinsic rate of population increase $\left(\mathrm{r}_{\mathrm{m}}\right)$, which is defined as the innate increase capacity of a population under ideal conditions; in other words, it corresponds to the population biotic potential (Price, 1984; Pedigo and Zeiss, 1996). A biological control agent is considered effective in the reduction of a certain pest if the $r_{m}$ parameter of both organisms is, at a minimum, similar (Van Lenteren, 2000). A favorable condition is established for the natural enemy in a certain area if the $r_{m}$ of the predator is superior to the intrinsic rates found for their prey.

Although, a life table was not established for the two-spotted spider mite in the present study, other authors have established it for their investigations and found that T. urticae $\mathrm{r}_{\mathrm{m}}$ values can vary significantly. Tetranychidae $r_{m}$ values can be higher when the generational duration is smaller and the fecundity is higher (Gutierrez and Helle, 1985), and T. urticae non-mated females can present a higher $r_{m}$ value than mated females (Silva et al., 2009). However, $r_{m}$ values may also be influenced by the nature or variety of the host plant as well as by temperature. For example, in different pear varieties at $27^{\circ} \mathrm{C}$ the T. urticae $\mathrm{r}_{\mathrm{m}}$ varied 
between 0.07 and 0.21 (Riahi et al., 2011). In the winter, the two-spotted spider mite $\mathrm{r}_{\mathrm{m}}$ value was 0.06 and in the autumn it was 0.19 on beanstalk leaves, and the average temperature was $26 \pm 1{ }^{\circ} \mathrm{C}$ (Hoque et al., 2008).

Although a variation for the values of T. urticae $\mathrm{r}_{\mathrm{m}}$ exists, it was concluded that $P$. macropilis is efficient in the control of $T$. urticae because the value cited previously $\left(r_{m}=0.19\right.$ female/female/day $)$ is higher or close to the values found in several studies on the same pest, as shown in the present study.

It has been shown that the higher the finite rate of increase $(\lambda)$, the higher the daily population growth. Nevertheless, in greenhouses and especially in the field, predators might be subject to several factors that can alter reproductive and developmental capacity. Thus, although laboratory tests are important and necessary, tests in greenhouses and in the field are also needed.

The mean generation time was similar to the numbers reported by Silva et al. (2005) for P. macropilis; by Canlas et al. (2006), Escudero and Ferragut (2005), Marafeli et al. (2014) and by Mesa et al. (1990) for N. californicus; and by Vasconcelos et al. (2008) for P. fragariae.

The finite rate of increase found $(\lambda)$ was similar to the values found by Ali (1998) and Silva et al. (2005) for P. macropilis; by Vasconcelos (2006) and Marafeli et al. (2014) for N. californicus; and by Vasconcelos et al. (2008) for P. fragariae, who also found similar net reproduction rate $\left(R_{0}\right)$ values.

\section{Conclusion}

The predatory mite Phytoseiulus macropilis can be considered a biological control agent for Tetranychus urticae since the P. macropilis intrinsic rate of population increase is higher than the pest intrinsic rate of increase.

\section{Acknowledgements}

To the National Council of Technology and Scientific Development (Conselho Nacional de Desenvolvimento Científico e Tecnológico - CNPq) for financial support and scholarships granted.

\section{References}

ABAD-MOYANO, R., PINA, T., FERRAGUT, F. and URBANEJA, A., 2009. Comparative life-history traits of three phytoseiid mites associated with Tetranychus urticae (Acari: Tetranychidae) colonies in clementine orchards in eastern Spain: implications for biological control. Experimental \& Applied Acarology, vol. 47, no. 2, pp. 121-132. http://dx.doi.org/10.1007/s10493-0089197-z. PMid:18931925.

ALATAWI, F., NECHOLS, J.R. and MARGOLIES, D.C., 2011. Spatial distribution of predators and prey affect biological control of twospotted spider mites by Phytoseiulus persimilis in greenhouses. Biological Control, vol. 56, no. 1, pp. 36-42. http:// dx.doi.org/10.1016/j.biocontrol.2010.09.006.

ALI, F., 1998. Life tables of Phytoseiulus macropilis (Banks) (Gamasida: Phytoseiidae) at different temperatures. Experimental
\& Applied Acarology, vol. 22, no. 6, pp. 335-342. http://dx.doi. org/10.1023/A:1024560924642.

CANLAS, L.J., MAMANO, H., OCHIAI, M. and TAKEDA, M., 2006. Biology and predation of the strain Japanese of Neoseiulus californicus (McGregor) (Acari: Phytoseiidae). Systematic and Applied Acarology, vol. 11, no. 2, pp. 141-157. http://dx.doi. org/10.11158/saa.11.2.2.

CHAPMAN, R.B. and MARTIN, N.A., 2005 [viewed 01 May 2015]. Spider mite resistance management strategy. In: N.A. MARTIN, R.M. BERESFORD and K.C. HARRINGTON, eds. Pesticide resistance: prevention and management strategies [online]. Hasting: New Zealand Plant Protection Society, pp 61-70. Available from: https://www.nzpps.org/books/2005_Resistance/ Resistance.pdf

DAVIES, J.T., IRESON, J.E. and ALLEN, G.R., 2009. Pre-adult development of Phytoseiulus persimilis on diets of Tetranychus urticae and Tetranychus lintearius: implications for the biological control of Ulex europaeus. Experimental \& Applied Acarology, vol. 47, no. 2, pp. 133-145. http://dx.doi.org/10.1007/s10493008-9198-y. PMid:18923915.

ESCUDERO, L.A. and FERRAGUT, F., 2005. Life-history of predatory mites Neoseiulus californicus and Phytoseiulus persimilis (Acari: Phytoseiidae) on four spider mite species as prey, with special reference to Tetranychus evansi (Acari: Tetranychidae). Biological Control, vol. 32, no. 3, pp. 378-384. http://dx.doi. org/10.1016/j.biocontrol.2004.12.010.

FADINI, M.A.M., VENZON, M., OLIVEIRA, H.G. and PALLINI, A., 2006. Manejo integrado das principais pragas do morangueiro. In: S.P. CARVALHO, org. Morango: cultivo convencional, segurança alimentar, cultivo orgânico. Belo Horizonte: FAEMG, vol. 1, pp. 81-95.

FERRERO, M., CALVO, F.J., ATUAHIVA, T., TIXIER, M.S. and KREITER, S., 2011. Biological control of Tetranychus evansi Baker \& Pritchard and Tetranychus urticae Koch by Phytoseiulus longipes Evans in tomato greenhouses in Spain [Acari: Tetranychidae, Phytoseiidae]. Biological Control, vol. 58, no. 1, pp. 30-35. http://dx.doi.org/10.1016/j.biocontrol.2011.03.012.

GRBIĆ, M., VAN LEEUWEN, T., CLARK, R.M., ROMBAUTS, S., ROUZÉ, P., GRBIĆ, V., OSBORNE, E.J., DERMAUW, W., NGOC, P.C., ORTEGO, F., HERNÁNDEZ-CRESPO, P., DIAZ, I., MARTINEZ, M., NAVAJAS, M., SUCENA, É., MAGALHÃES, S., NAGY, L., PACE, R.M., DJURANOVIĆ, S., SMAGGHE, G., IGA, M., CHRISTIAENS, O., VEENSTRA, J.A., EWER, J., VILLALOBOS, R.M., HUTTER, J.L., HUDSON, S.D., VELEZ, M., YI, S.V., ZENG, J., PIRES-DA-SILVA, A., ROCH, F., CAZAUX, M., NAVARRO, M., ZHUROV, V., ACEVEDO, G., BJELICA, A., FAWCETT, J.A., BONNET, E., MARTENS, C., BAELE, G., WISSLER, L., SANCHEZ-RODRIGUEZ, A., TIRRY, L., BLAIS, C., DEMEESTERE, K., HENZ, S.R., GREGORY, T.R., MATHIEU, J., VERDON, L., FARINELLI, L., SCHMUTZ, J., LINDQUIST, E., FEYEREISEN, R. and VAN DE PEER, Y., 2011. The genome of Tetranychus urticae reveals herbivorous pest adaptations. Nature, vol. 479, no. 7374, pp. 487-492. http:// dx.doi.org/10.1038/nature10640. PMid:22113690.

GUTIERREZ, J. and HELLE, W., 1985. Evolutionary changes in the Tetranychidae. In: W. HELLE and M.W. SABELIS, eds. Spider mites: their biology, natural enemies and control. Amsterdam: Elsevier Science, vol. 1A, pp. 91-107.

HOQUE, M.F., ISLAM, W. and KHALEQUZZAMAN, M., 2008. Life tables of two-spotted spider mite Tetranychus urticae Koch (Acari: Tetranychidae) and its predator Phytoseiulus persimilis 
Athias-Henriot (Acari: Phytoseiidae). Bioscience Journal, vol. 16, pp. 1-10. http://dx.doi.org/10.3329/jbs.v16i0.3733.

MARAFELI, P.P., REIS, P.R., SILVEIRA, E.C., SOUZAPIMENTEL, G.C. and TOLEDO, M.A., 2014. Life history of Neoseiulus californicus (McGregor, 1954) (Acari: Phytoseiidae) fed with castor bean (Ricinus communis L.) pollen in laboratory conditions. Brazilian Journal of Biology $=$ Revista Brasileira de Biologia, vol. 74, no. 3, pp. 691-697. http://dx.doi.org/10.1590/ bjb.2014.0079.

MCMURTRY, J.A. and SCRIVEN, G.T., 1964. Studies on the feeding, reproduction, and development of Amblyseius hibisci (Acarina: Phytoseiidae) on various food substances. Annals of the Entomological Society of America, vol. 57, no. 5, pp. 649-655. http://dx.doi.org/10.1093/aesa/57.5.649.

MCMURTRY, J.A., SOURASSOU, N.F. and DEMITE, P.R., 2015. The Phytoseiidae (Acari: Mesostigmata) as biological control agents. In: D. CARRILO, G.J. MORAES and J.E. PEÑA, eds. Prospects for biological control of plant feeding mites and other harmful organisms. New York: Springer, pp. 133-149.

MESA, N.C., BRAUN, A.R. and BELOTTI, A.C., 1990. Comparison of Mononychellus progresivus as prey for five species of phytoseiid mites. Experimental \& Applied Acarology, vol. 9, no. 3-4, pp. 159-168. http://dx.doi.org/10.1007/BF01193425.

MORAES, G.J. and FLECHTMANN, C.H.W., 2008. Manual de acarologia: acarologia básica écaros de plantas cultivadas no Brasil. Ribeirão Preto: Holos, pp. 106-199.

MORAES, G.J., 2002. Controle biológico de ácaros fitófagos com predadores. In: J.R.P. PARRA, P.S.M. BOTELHO, B.S. CORREAAFERREIRA and J.M.S. BENTO, eds. Controle biológico no Brasil: parasitóides e predadores. São Paulo: Manole, pp. 225-237.

OLIVEIRA, H., FADINI, M.A.M., VENZON, M., REZENDE, D., REZENDE, F. and PALLINI, A., 2009. Evaluation of the predatory mite Phytoseiulus macropilis Banks (Acari: Phytoseiidae) as a biological control agent of the twospotted spider mite on strawberry plants under greenhouse conditions. Experimental \& Applied Acarology, vol. 47, no. 4, pp. 275-283. http://dx.doi. org/10.1007/s10493-008-9217-z. PMid:19016335.

OLIVEIRA, H., JANSSEN, A., PALLINI, A., VENZON, M., FADINI, M. and DUARTE, V., 2007. A phytoseiid predator from the tropics as potential biological control agent for the spider mite Tetranychus urticae Koch (Acari: Tetranychidae). Biological Control, vol. 42, no. 2, pp. 105-109. http://dx.doi.org/10.1016/j. biocontrol.2007.04.011.

OPIT, G.P., NECHOLS, J.R. and MARGOLIES, D.C., 2004. Biological control of twospotted spider mites, Tetranychus urticae Koch (Acari: Tetranychidae), using Phytoseiulus persimilis Athias-Henriot (Acari: Phytoseidae) on ivy geranium: assessment of predator release ratios. Biological Control, vol. 29, no. 3, pp. 445-452. http://dx.doi.org/10.1016/j.biocontrol.2003.08.007.

PEDIGO, L.P. and ZEISS, M.R., 1996. Developing a degree-day model for predicting insect development. In: L.P. PEDIGO and M.R. ZEISS, eds. Analyses in insect ecology and management. Ame: Iowa State University, pp. 67-74.

POLETTI, M., KONNO, R.H., SATO, M.E. and OMOTO, C., 2006. Controle Biológico aplicado do ácaro rajado em cultivo protegido: viabilidade no emprego dos ácaros predadores. In: A.S. PINTO, D.E. NAVA, M.M. ROSSI and D.T. MALERBO-SOUZA, orgs. Controle biológico de pragas: na prática. Piracicaba: FEALQ, pp. 193-203.
PRASAD, V., 1967. Biology of the predatory mite Phytoseiulus macropilis in Hawaii (Acarina: Phytoseiidae). Annals of the Entomological Society of America, vol. 60, no. 5, pp. 905-908. http://dx.doi.org/10.1093/aesa/60.5.905.

PRICE, P.W., 1984. Insect ecology. 2nd ed. New York: John Wiley. $607 \mathrm{p}$

REIS, P.R., CHIAVEGATO, L.G. and ALVES, E.B., 1998. Biologia de Iphiseiodes zuluagai Denmark \& Muma (Acari: Phytoseiidae). Anais da Sociedade Entomológica do Brasil, vol. 27, no. 2, pp. 185-191. http://dx.doi.org/10.1590/S0301-80591998000200003.

REIS, P.R., SILVA, E.A. and ZACARIAS, M.S., 2005. Controle biológico de ácaros em cultivos protegidos. Informe Agropecuário, vol. 26 , no. 225 , pp. $58-67$.

REIS, P.R., TEODORO, A.V., PEDRO NETO, M. and SILVA, E.A., 2007. Life history of Amblyseius herbicolus (Chant) (Acari: Phytoseiidae) on coffee plants. Neotropical Entomology, vol. 36, no. 2, pp. 282-287. http://dx.doi.org/10.1590/S1519566X2007000200016. PMid:17607463.

RIAHI, E., NEMATI, A., SHISHEHBOR, P. and SAEIDI, Z., 2011. Population growth parameters of the two-spotted spider mite, Tetranychus urticae, on three peach varieties in Iran. Acarologia, vol. 51, no. 4, pp. 473-480. http://dx.doi.org/10.1051/ acarologia/20112029.

SATO, M.E., SILVA, M., GONÇALVES, L.R., SOUZA FILHO, M.F. and RAGA, A., 2002. Toxicidade diferencial de agroquímicos a Neoseiulus californicus (McGregor) (Acari: Phytoseiidae) e Tetranychus urticae Koch (Acari: Tetranychidae) em morangueiro. Neotropical Entomology, vol. 31, no. 3, pp. 449-456. http://dx.doi. org/10.1590/S1519-566X2002000300016.

SATO, M.E., SILVA, M.Z., CANGANI, K.G. and RAGA, A., 2007. Seleções para resistência e suscetibilidade, detecção e monitoramento da resistência de Tetranychus urticae Koch (Acari: Tetranychidae) ao acaricida clorfenapir. Bragantia, vol. 66, pp. 89-95. http://dx.doi.org/10.1590/S0006-87052007000100011.

SATO, M.E., SILVA, M.Z., SILVA, R.B., SOUZA FILHO, M.F. and RAGA, A., 2009. Monitoramento da resistência de Tetranychus urticae Koch (Acari: Tetranychidae) a abamectin e fenpyroxymate em diversas culturas no Estado de São Paulo. Arquivos do Instituto Biologico, vol. 76, no. 2, pp. 217-223.

SILVA, E.A., REIS, P.R., CARVALHO, T.M.B. and ALTOÉ, B.F., 2009. Tetranychus urticae (Acari: Tetranychidae) on Gerbera jamesonii Bolus and Hook (Asteraceae). Brazilian Journal of Biology $=$ Revista Brasileira de Biologia, vol. 69, no. 4, pp. 1121-1125. http://dx.doi.org/10.1590/S1519-69842009000500016. PMid:19967183.

SILVA, F.R., VASCONCELOS, G.J.N., GONDIM JUNIOR, M.G.C. and OLIVEIRA, J.V., 2005. Exigências térmicas e tabela de vida de fertilidade de Phytoseiulus macropilis (Banks) (Acari: Phytoseiidae). Neotropical Entomology, vol. 34, no. 2, pp. 291296. http://dx.doi.org/10.1590/S1519-566X2005000200017.

SILVEIRA NETO, S., NAKANO, O., BARBIN, D. and VILANOVA, N.A., 1976. Manual de ecologia dos insetos. São Paulo: Ceres. $419 \mathrm{p}$

TANIGOSHI, L.K., HOYT, S.C., BROWNE, R.W. and LOGAN, J.A., 1975. Influence of temperature on population increase of Metaseiulus occidentalis (Acarina: Phytoseiidae). Annals of the Entomological Society of America, vol. 68, no. 6, pp. 979-986. http://dx.doi.org/10.1093/aesa/68.6.979. 
VAN LENTEREN, J.C., 2000. A greenhouse without pesticides: fact or fantasy? Crop Protection (Guildford, Surrey), vol. 19, no. 6, pp. 375-384. http://dx.doi.org/10.1016/S0261-2194(00)00038-7.

VASCONCELOS, G.J.N. 2006. Eficiência dos ácaros predadores Phytoseiulus fragariae e Neoseiulus californicus (Acari: Phytoseiidae) em Licopersicon esculentum e Solanum americanum. Piracicaba: Escola Superior de Agricultura Luiz de Queiroz, Universidade de São Paulo, 81 p. Dissertação de Mestrado em Entomologia.
VASCONCELOS, G.J.N., MORAES, G.J., DELALIBERA JUNIOR, I. and KNAPP, M., 2008. Life history of the predatory mite Phytoseiulus fragariae on Tetranychus evansi and Tetranychus urticae (Acari: Phytoseiidae, Tetranychidae) at five temperatures. Experimental \& Applied Acarology, vol. 44, no. 1, pp. 27-36. http://dx.doi.org/10.1007/s10493-007-9124-8. PMid:18058026.

ZHANG, Z.Q., 2003. Mites in greenhouse: identification, biology and control. Cambridge: CABI Publishing. 244 p. 